Hātererāt-e Bozorg 'Alavī. Hamīd Aḥmadī, éd., Tehrān, Donyā-ye Ketāb, 1377/1998, 442 p. + 27 ill. + 27 p. d'index non paginées. [Mémoires de Bozorg 'Alavī]

\title{
Christophe Balaÿ
}

\section{OpenEdition}

1 Journals

\section{Édition électronique}

URL : http://journals.openedition.org/abstractairanica/37084

DOI : 10.4000/abstractairanica.37084

ISSN : 1961-960X

Éditeur :

CNRS (UMR 7528 Mondes iraniens et indiens), Éditions de l'IFRI

\section{Édition imprimée}

Date de publication : 15 mai 2001

ISSN : 0240-8910

Référence électronique

Christophe Balaÿ, « Hāțerāt-e Bozorg 'Alavī. Hamīd Ahmadī, éd., Tehrān, Donyā-ye Ketāb, 1377/1998, 442 p. +27 ill. + 27 p. d'index non paginées. [Mémoires de Bozorg 'Alavi]] », Abstracta Iranica [En ligne], Volume 22 | 2001, document 519, mis en ligne le 17 février 2010, consulté le 10 octobre 2020. URL : http://journals.openedition.org/abstractairanica/37084; DOI : https://doi.org/10.4000/ abstractairanica.37084

Ce document a été généré automatiquement le 10 octobre 2020.

Tous droits réservés 
Huāterāt-e Bozorg 'Alavī. Hamīd Aḥmadī, éd., Tehrān, Donyā-ye Ketāb, 1377/1998, 442 p. + 27 ill. + 27 p. d'index non paginées. [Mémoires de Bozorg 'Alavī]

\author{
Christophe Balaÿ
}

Hamīd Ahmadī publie ici une série d'entretiens avec l'écrivain B. 'Alavī (1904-1997). L'histoire orale, en Iran, en est à ses débuts, comme l'indique le responsable du projet d'histoire orale de la gauche iranienne (1920-1990). C'est la troisième tentative dans ce domaine appliquée à l'Iran après celle de l'Université d'Harvard (800 h. d'entretiens, de 1981 à 1987, de 133 personnalités qui jouèrent un rôle dans l'histoire politique de l'Iran des années 1920 à 1970). Le deuxième projet concernait les femmes iraniennes aux USA. Les entretiens avec B. 'Alavī sont donnés ici en version papier mais la version CD rom est en préparation. Il s'agit de 29 séances d'entretiens étalées sur onze mois pendant l'année 1995, en 24 films video (tournés un an et demi avant la mort de l'auteur). H. Aḥmadĩ dans son introduction explique sa méthode d'histoire orale et le caractère scientifique des données recueillies. On a donc là, avec un index des noms, une somme de renseignements de première main sur la vie de l'écrivain engagé que fut B. 'Alavī, sur la vie politique et sociale dans l'Iran des années 20, celle des opposants politiques sous les Pahlavi. Ces entretiens abordent aussi abondamment l'œuvre littéraire qui ponctue la longue vie d'exil de l'écrivain. 
INDEX

Thèmes : 11.1.2. Littérature persane moderne

\section{AUTEURS}

CHRISTOPHE BALAY

IFRI - Téhéran 